\title{
PERAN PENGELOLAAN DAN PENGEMBANGAN SUMBER DAYA MANUSIA UNTUK PENINGKATAN KINERJA PERUSAHAAN (STUDI PADA PT. PRIBUMI CITRA MEGAH UTAMA)
}

\author{
Noorlaily Maulida \\ E-mail: Periyadi401@gmail.com \\ Periyadi \\ Junaidi
}

Fakultas Ekonomi UNISKA MAB Banjarmasin

\begin{abstract}
The main objective in this study is to examine and analyze how the influence of human resource development consisting of, recruitment, training, career development, compensation, promotion of position on company performance.

This research was conducted with a qualitative method and using the SWOT analysis as a data analysis tool. The object of this research is PT. Pribumi Citra Megah Utama, which runs its businesses such as hotels, shopping centers, housing, financing and mining in South Kalimantan. Data that has been tested for its credibility with the triangulation technique of data sources, is then analyzed descriptively using the help of a data analysis model developed by Miles and Huberman. Miles and Huberman made a model of data analysis consisting of three stages, namely: data reduction, data display, and conclusion drawing.

Based on the results of research it can be found that the human resource management strategy plan to increase the productivity of employees of PT. Pribumi Citra Megah Utama is a business partner model strategy because this strategy has several advantages, namely the existence of several strengths in the company that can be used to take advantage of several opportunities and face several threats to the company. The methods carried out by PT. Pribumi Citra Megah Utama is to Reinforce and tighten company regulations which include working hours, employee responsibilities, work completion, accuracy of work completion.
\end{abstract}

Keywords: Strategy, Performance, Human Resources.

\section{PENDAHULUAN}

Perusahaan yang mampu bertahan dalam menghadapi krisis ekonomi yang berkepanjangan bukanlah perusahaan yang hanya mengandalkan keuangan perusahaan tersebut. Karena disamping pendanaan, perusahaan memiliki sumber daya yang lain yang tidak kalah pentingnya yaitu sumber daya manusia (Francisca Robert, 2017). Selain itu perusahaan juga ingin memberikan kepuasan kepada pelanggan atas produk atau jasa yang yang dihasilkannya, karena kepuasan pelanggan. Pencapaian dengan strategi pemasaran yang tepat dan terbaik untuk diterapkan, salah satunya perusahaan dapat melihat dari faktor 
pengelolaan sumber daya manusia yang diukur dari produktivitas sumber daya manusia secara individu dan secara teamwork yang terbentuk kedalam struktur organisasi dalam perusahaan.

Kinerja merupakan hasil pekerjaan yang mempunyai hubungan kuat dengan tujuan strategis organisasi, kepuasan konsumen dan memberikan kontribusi pada ekonomi (Armstrong dan Baron, 1998). Kinerja adalah tentang melakukan pekerjaan dan hasil yang dicapai dari pekerjaan tersebut. Kinerja adalah tentang apa yang dikerjakan dan bagaimana cara mengerjakannya. Sumber daya manusia digunakan secara signifikan sebagai penggerak sumber daya lain dan memiliki posisi strategis yang berkontribusi untuk mewujudkan kinerja organisasi perusahaan dengan keunggulan kompetitif (Wright: 2005). Paulus dan Anantharaman (2003) menegaskan pengembangan sumber daya manusia memiliki hubungan langsung dengan profitabilitas organisasi.

PT. Pribumi Citra Megah Utama merupakan salah satu perusahaan yang berkembang pesat di daerah Kalimantan Selatan khususnya Banjarmasin. Perusahaan ini berdiri sejak tahun 1995 yang bergerak dibidang pertambangan, perhotelan, pusat perbelanjaan serta pada sektor perumahan. Oleh karena itu, dari sekian banyak sektor usaha yang dijalankan oleh perusahaan perlu didukung dengan sumberdaya yang memadai dan diatas rata-rata agar tujuan perusahaan tercapai. Sumber Daya Manusia mempunyai peran utama dalam setiap kegiatan perusahaan. Walaupun didukung dengan sarana dan prasarana serta Sumber Daya yang berlebih, tetapi tanpa dukungan Sumber Daya Manusia yang handal maka kegiatan perusahaan tidak akan terselesaikan dengan baik.

\section{TINJAUAN TEORITIS}

\section{A. Kinerja}

Kinerja adalah hasil atau tingkat keberhasilan seseorang secara keseluruhan selama periode tertentu didalam melaksanakan tugas dibandingkan dengan berbagai kemungkinan, seperti standar hasil kerja, target atau sasaran atau kriteria yang telah ditentukan terlebih dahulu dan telah disepakti bersama (Rivai \& Basri,2005).

Menurut Hersey \& Blanchard, kinerja adalah suatu fungsi dari motivasi dan kemampuan. Untuk menyelesaikan tugas atau pekerjaan, seseorang harus memiliki derajat kesediaan dan tingkat kemampuan tertentu. Kesediaan dan tingkat keterampilan seseorang tidaklah cukup efektif untuk mengerjakan sesuatu tanpa pemahaman yang jelas tentang apa yang akan dikerjakan dan bagaimana mengerjakannya (Rivai \& Basri, 2005). 
Menurut Mangkunegara (2005), faktor penentu prestasi kerja individu dalam organisasi adalah faktor individu dan faktor lingkungan.

a. Faktor Individu

Secara psikologis, individu yang normal adalah individu yang memiliki integritas yang tinggi antara fungsi psikis dan fisiknya. Konsentrasi yang baik ini merupakan modal utama individu untuk mampu mengelola dan mendayagunakan potensi dirinya secara optimal dalam melaksanakan kegiatan atau aktifitas kerja sehari-hari dalam mencapai tujuan organisasi.

b. Faktor Lingkungan

Faktor lingkungan kerja organisasi sangat menunjang bagi individu dalam mencapai prestasi kerja. Faktor lingkungan organisasi yang dimaksud antara lain uraian jabatan yang jelas, autoritas yang memadai, target kerja yang menantang, pola komunikasi kerja efektif, hubungan kerja harmonis, iklim kerja respek dan dinamis, peluang berkarier dan fasilitas kerja yang relatif memadai.

\section{Penilaian Kinerja}

Penilaian Kinerja adalah upaya untuk mengetahui kinerja pegawai dalam melaksanakan tugas-tugas yang diembannya. Menurut Barcal (2001) menyatakan bahwa penilaian kinerja (performance appraisal), pengkajian ulang kinerja (performance review), evaluasi kinerja (performance evaluation) adalah tiga istilahyang dapat menggantikan satu sama lain untuk mendeskripsikan pertemuan tahunan dimana manajer dan karyawanmemperbincangkan kinerja karyawan, mendokumentasikan kemajuan (sukses maupun masalah), dan menerapkan pendekatan pemecahan masalah tertentu untuk mengatasi permasalahan yang terjadi saat ini maupun dimasa yang akan datang.

\section{Indikator Variabel Kinerja}

Dalam melakukan penilaian kinerja pegawai diperlukan instrumen-instrumen yang secara representative dapat menggambarkan suatu kinerja.

Menurut Benardin \& Russell (1998) ada 6 (enam) kriteria primer yang dapat digunakan untuk mengukur kinerja :

a. Quality, merupakan tingkat sejauh mana proses atau hasil pelaksanaan kegiatan mendekati kesempurnaan atau mendekati tujuan yang diharapkan.

b. Quantity, merupakan jumlah yang dihasilkan, misalnya jumlah rupiah, jumlah unit, jumlah siklus kegiatan yang diselesaikan. 
c. Timeliness adalah tingkat sejauh mana suatu kegiatan diselesaikan pada waktu yang dikehendaki dengan memperhatikan koordinasi output lain serta waktu yang tersedia untuk kegiatan lain.

d. Cost - effectiveness adalah tingkat sejauh mana penggunaan daya organisasi (manusia, keuangan, teknologi, material) dimaksimalkan untuk mencapai hasil tertinggi atau pengurangan kerugian dari setiap unit penggunaan sumber daya .

e. Needs for supervision, adalah tingkat sejauh mana seseorang pekerja dapat melaksanakan suatu fungsi pekerjaan tanpa memerlukan pengawasan seorang supervisor untuk mencegah tindakan yang kurang diinginkan.

f. Interpersonal impact, merupakan tingkat sejauh mana karyawan memelihara harga diri, nama baik dan kerjasama diantara rekan kerja dan bawahan.

\section{Kinerja Perusahaan}

Cornelius (2007) kinerja perusahaan merupakan hal penting yang harus dicapai oleh setiap perusahaan dimanapun, karena kinerja merupakan cerminan dari kemampuan perusahaan dalam mengelola dan mengalokasikan sumber dayanya. Sistem pengukuran kinerja yang baik adalah sekumpulan ukuran kinerja yang menyediakan perusahaan dengan informasi yang berguna,sehingga membantu mengelola, mengontrol, merencanakan, dan melaksanakan aktivitasaktivitas yang dilakukan oleh perusahaan.

\section{B. Manajemen Sumber Daya Manusia}

Sumber daya manusia merupakan salah satu sumber daya yang paling menentukan sukses tidaknya suatu organisasi. Berbeda dengan sumber daya organisasi lainnya, sumber daya manusia merupakan faktor produksi yang memiliki mempunyai pengaruh yang dominan terhadap faktor produksi yang lain seperti mesin,modal,material, dan metode. Oleh karena itu, organisasi dituntut untuk mengelola sumber daya manusia yang dimiliki dengan baik demi kelangsungan hidup dan kemajuan organsiasi.

Menurut Malayu S.P Hasibuan (2013) Manajemen SDM merupakan bagian dari manajemen umum yang memfokuskan dari pada SDM. Adapun fungsi - fungsi manajemen SDM, seperti halnya fungsi manajemen umum, yaitu:

\section{a. Perencanaan (planning)}

Merencanakan tenaga kerja secara efektif serta efisien agar sesuai dengankebutuhan perusahaan dalam rangka membantu terwujudnya tujuan.

b. Pengorganisasian (organization) 
Kegiatan untuk mengorganisasi semua karyawan dengan menetapkanpembagian kerja, hubungan kerja, delegasi wewenang,integrasi dan koordinasidalam bagan organisasi.

c. Pengarahan (directing)

Kegiatan mengarahkan semua karyawan agar mau bekerjasama dan bekerja efektif dan efisien dalam membantu terwujudnya tujuan perusahaan.

d. Pengendalian (controlling)

Kegiatan mengendalikan semua karyawan agar mentaati peraturan-peraturan perusahaan dan bekerja sesuai rencana. Apabila terdapat penyimpangan atau kesalahan maka diadakan tindakan perbaikan dan penyempurnaan rencana.

e. Pengadaan (procurement)

Proses penarikan, seleksi, penempatan, orientasi dan induksi untuk mendapatkan karyawan yang sesuai dengan kebutuhan perusahaan.

f. Pengembangan (development)

Proses peningkatan keterampilan teknik, teoritis, konseptual, dan moral karyawan melalui pendidikan dan pelatihan. Pendidikan dan pelatihan yang diberikan harus sesuai dengan kebutuhan pekerjaan masa kini maupun masadepan.

g. Kompensasi (compensation)

Pemberian balas jasa langsung (direct) dan tidak langsung (inderect), uang atau barang kepada karyawan sebagai imbalan jasa yang diberikan kepada perusahaan.

h. Pengintegrasian (integration)

Kegiatan untuk mempersatukan kepentingan perusahaan dan kebutuhan karyawan, agar tercipta kerjasama yang serasi dan saling menguntungkan.Perusahaan akan memperoleh laba sedangkan karyawan dapat memenuhi kebutuhan dari hasil pekerjaannya.

i. Pemeliharaan (maintenance)

Kegiatan untuk memelihara atau meningkatkan kondisi fisik, mental danloyalitas karyawan agar mereka tetap mau bekerja sama sampai pensiun.

\section{Pengembangan Sumber Daya Manusia}

\section{Pengertian Pengembangan Sumber Daya Manusia}

Menurut Singodimedjo (2002) pengembangan sumber daya manusia adalah proses persiapan individu-individu untuk memikul tanggung jawab yang berbeda atau lebih tinggi 
didalam organisasi, biasanya berkaitan dengan peningkatan kemampuan intelektual untuk melaksanakan pekerjaan yang lebih baik. Menurut Malayu Hasibuan (2000) mengemukakan pengertian pengembangan sumber daya manusia adalah suatu usaha untuk meningkatkan kemampuan teknis, teoritis, konseptual dan moral karyawan sesuai dengankebutuhan pekerjaan atau jabatan.

\section{Metode Pengembangan Sumber Daya Manusia}

Berikut metode dalam pengembangan sumber daya manusia:

a. Pendidikan dan Pelatihan

Menurut Hasibuan (2002) pendidikan dan pelatihan adalah merupakanproses peningkatan keterampilan kerja baik teknik maupun manajerial. Menurut Soekidjo Notoatmodjo (2003) Pendidikan dan pelatihanadalah merupakan upaya untuk mengembangkan sumber daya manusia, terutamauntuk mengembangkan intelektual dan keperibadian manusia.

b. Tugas Belajar

Sesuai dengan Peraturan Presiden No. 12 Tahun 1961 tentang pemberiantugas belajar, tugas belajar diberikan untuk menuntut ilmu, mendapatkanpendidikan atau latihan keahlian baik di dalam maupun di luar negeri denganbiaya negara atau sesuatu pemerintah negara asing, sesuatu badan internasional, atau sesuatu badan swasta asing.

c. Promosi

Menurut Alex Nitisemito (2006) promosi adalah proses kegiatanpemindahan pegawai/karyawan, dari satu jabatan atau tempat lain yang lebihtinggi serta diikuti oleh tugas, tanggung jawab, dan wewenang yang lebih tinggi dari jabatan yang diduduki sebelumnya.Menurut William B. Wether dan Keith Davis (2004) Promosi terjadi ketika seorang karyawan dipindahkan dari satu jabatan ke jabatan lain yang lebih tinggi imbalan, tanggungjawab dan tingkatannya dalam organisasi.

d. Kinerja

Menurut Hasibuan (2008) kinerja adalah suatu hasil kerja yang dicapaiseseorang dalam melaksanakan tugas-tugas yang dibebankan kepadanya yangdidasarkan atas kecakapan, pengalaman dan kesungguhan serta waktu.

\section{Analisis SWOT}

Analisis SWOT merupakan sebuah alat pencocokan yang penting yang membantu para manajer mengembangkan empat jenis strategi, yaitu strategi SO (kekuatan-peluang), strategi WO (kelemahan-peluang), strategi ST(kekuatan-ancaman), dan strategi WT 
(kelemahan-ancaman). Penjelasan dari konsep yang terdapat dalam elemen-elemen analisis SWOT sebagai berikut:

\section{a. Strength}

Strength merupakan kemampuan lebih yang dimiliki oleh internal perusahaan dibandingkan dengan pesaing lain. Strength juga dijadikan sebagai suatu kompetensi perusahaan yang merupakan pembanding dengan pesaing.

b. Weakness

Weakness merupakan kelemahan yang berasal dari internal perusahaan tersebut. Biasanya pada sisi inilah pesaing mencari peluang untuk menjatuhkan musuh.

c. Opportunity

Opportunity merupakan kesempatan atau peluang yang dimiliki oleh perusahaan dan apabila perusahaan memperhatikannya dengan jeli maka merupakan peluang untuk menjadikan diferensiasi dengan pesaing lainnya.

d. Threats

Threats merupakan ancaman yang berasal dari eksternal perusahaan yang bisa merugikan perusahaan sehingga perusahaan harus segera mengatasinya.

\section{METODE PENELITIAN}

\section{Jenis Penelitian}

Jenis Penelitian ini menggunakan metode kualitatif. Menurut Sugiyono (2011), metode kualitatif dapat berfungsi untuk menggambarkan dan memahami makna di balik data-data yang tampak.

Objek dalam penelitian ini adalah PT. Pribumi Citra Megah Utama yang menjalankan usahanya seperti perhotelan, pusat perbelanjaan, perumahan, pembiyaan dan pertambangan di Kalimantan Selatan.

\section{Teknik Analisis Data}

Data-data yang telah diuji kredibilitasnya dengan teknik triangulasi sumber data, kemudian dianalisis secara deskriptif dengan menggunakan bantuan model analisis data yang dikembangkan oleh Miles dan Huberman (dalam Sugiyono, 2011). Miles dan Huberman membuat model analisis data yang terdiri dari tiga tahapan, yaitu: reduksi data (data reduction), penyajian data (data display), dan penarikan kesimpulan.

\section{HASIL PENELITIAN DAN PEMBAHASAN}




\section{A. Hasil Penelitian}

\section{Analisis Lingkungan Internal}

Pada lingkungan internal perusahaan, terdiri dari beberapa kekuatan yang dapat berpengaruh terhadap perusahaan yakni:

\section{a. Produksi dan Operasional}

Manajemen produksi menangani input, transformasi, dan output yang beragam dari satu industri dan pasar ke industri dan pasar yang lain. Operasi manufaktur merupakan serangkaian kegiatan menstransformasi atau mengubah input seperti bahan mentah, tenaga kerja, modal, mesin, dan fasilitas menjadi barang atau jasa.

Produksi dan operasional yang terdapat di PT. Pribumi Citra Megah Utama merupakan kegiatan menciptakan barang/jasa perumahan, perhotelan dan lain-lain yang meliputi kegiatan administrasi agar bernilai tambah dengan melalui proses transformasi. PT. Pribumi Citra Megah Utama memproses produksi dari jasa yang ditawarkan berupa perumahan, Perhotelan dan lain-lain. Dalam kaitannya dengan pencapaian tujuan yang telah ditetapkan perusahaan, PT. Pribumi Citra Megah Utama dalam melakukan aktivitas operasionalnya telah menerapkan fungsi manajemen yang mencakup perencanaan, pengorganisasian, pengendalian dan pengawasan. Proses produksi yang dilakukan PT. Pribumi Citra Megah Utama apabila kinerja jasa ditunjukkan oleh perusahaan dengan baik, maka proses pemasaran akan berjalan dengan sendirinya, dan proses produksi jasa yang ada di PT. Pribumi Citra Megah Utama tidak dipublikasikan secara umum.

Berdasarkan pada hasil wawancara dengan salah satu responden dalam penelitian initelah didapatkan analisis dari aspek produksi dan operasional adalah menentukan tujuan untuk kelangsungan operasional perusahaan, yaitu pengadaan jasa perhotelan, perumahan tempat tinggal untuk menunjang kinerja perusahaan.PT. Pribumi Citra Megah Utama dalam membuat kondisi kerja supaya bisa berjalan secara kondusif, mengupayakan dan menciptakan transparatif dan terbuka antara karyawan dengan pimpinan dalam bermusyawarah, dan supaya karyawan bagian produksi dan operasional bisa bekerja secara efektif dan efisien, maka PT. Pribumi Citra Megah Utama memberlakukan evaluasi yang dilakukan setiap hari Sabtu terhadap karyawan yang baru bergabung. Dalam hal pengambilan keputusan dilakukan dengan mengadakan musyawarah antar pimpinan, yang kemudian hasil musyawarah dimusyawarahkan kembali dengan karyawan. 
Salah satu langkah inspiratif yang dilakukan PT. Pribumi Citra Megah Utama kepada divisi produksi dan operasional adalah dengan memberikan bonus pada karyawan yang menunjukkan prestasinya di bidang produksi dan operasional. Untuk menciptakan hubungan komunikasi dengan karyawan. PT. Pribumi Citra Megah Utama dalam melakukan pengawasan yaitu dengan melalui leader masing-masing group dan juga melalui daily check list tiap kali pergantian shift. Apabila dalam kegiatan produksi dan operasional ditemukan suatu penyimpangan, PT. Pribumi Citra Megah Utama melakukan tindakan korektif berupa memberikan peringatan secara lisan, dan selama ini dalam melakukan kegiatan pengawasan di produksi dan operasional, PT. Pribumi Citra Megah Utama masih terdapat kendala yaitu kurangnya supervisi lapangan untuk melakukan pengawasan secara 24 jam.

\section{b. Pemasaran}

Memiliki produk yang kompetitif tidaklah cukup bagi PT. Pribumi Citra Megah Utama . Produk kompetitif haruslah didukung dengan para pelaku bisnis yang memiliki kemampuan dalam pemasaran. Hal demikian dikarenakan bahwa pemasaran bukan hanya sebagai kegiatan penjualan produk, namun penjualan merupakan bagian dari pemasaran. Pemasaran yang terdapat di PT. Pribumi Citra Megah Utama adalah berupa kegiatan menawarkan dan menjual jasa layanan perhotelan, perumahan tempat tinggaldan pusat perbelanjaan yang merupakan produk utama bagi perusahaan. Pemasaran bagi PT. Pribumi Citra Megah Utama merupakan proses sosial dan manajerial yang didalamnya terdapat individu dan kelompok dalam mendapatkan kebutuhan dan keinginan dengan menciptakan, menawarkan dan menukarkan produk yang bernilai dengan pihak lain.

PT. Pribumi Citra Megah Utama dalam mengidentifikasi permintaan pasar adalah dengan melalui mouth of mouth serta mendapat informasi dari koneksi perusahaan. Dalam hal untuk memenuhi permintaan pasar, PT. Pribumi Citra Megah Utama memiliki pasar sendiri, dan juga memiliki bidang jasa sendiri, sehingga PT. Pribumi Citra Megah Utama selalu berupaya untuk semaksimal mungkin bisa memenuhi permintaan pasar tersebut. PT. Pribumi Citra Megah Utama sudah dalam proses pembangunan berkaitan dengan pengalokasian upaya pemasaran dalam kaitannya dengan potensi keuntungan jangka panjang.

Penyaluran distribusi yang terdapat di PT. Pribumi Citra Megah Utama selama melakukan kegiatan pemasaran adalah lancar-lancar saja sesuai dengan tugas serta tanggung jawab masing-masing karyawan. Kegiatan pemasaran PT. Pribumi Citra Megah Utama 
belum bisa berjalan dengan optimal, karena proses kegiatan pemasaran masih bergantung pada channel dan koneksi. PT. Pribumi Citra Megah Utama dalam mengukur citra perusahaan atas kepuasan yang didapat pelanggan adalah dengan cara memperhatikan dan mengkaji bagaimana customer bisa melihat kinerja PT. Pribumi Citra Megah Utama, dalam artian apabila customer puas dengan produk layanan PT. Pribumi Citra Megah Utama, maka sudah pasti customer akan memakai kembali jasa layanan perusahaan.

\section{c. Keuangan}

Kekuatan keuangan terkait dengan dua hal, yaitu: keputusan investasi dan keputusan pembiayaan. Dalam membuka suatu usaha memerlukan berbagai sumber daya, baik itu sumber daya manusia, bahan baku, mesin, bangunan, peralatan maupun kapital atau dana. Kapital atau dana itu sendiri merupakan sebuah nyawa bagi suatu usaha. Adanya kekurangan pada kapital atau dana maka akan membuat suatu usaha tersebut menjadi lesu. Keuangan pada PT. Pribumi Citra Megah Utama berkaitan dengan keputusan masalah investasi yang terdapat di perusahaan, yaitu merupakan keputusan masalah investasi terhadap fungsi-fungsi bisnis yang terdapat di PT. Pribumi Citra Megah Utama yang berupa keterkaitannya dengan keputusan proses pemilihan alternatif investasi dengan tujuan untuk keuntungan perusahaan, dan keputusan keuangan yang terdapat di PT. Pribumi Citra Megah Utama berada ditangan pimpinan puncak.

PT. Pribumi Citra Megah Utama dalam kaitannya dengan pengambilan keputusan dilakukan oleh pimpinan melalui musyawarah, yang kemudian hasil musyawarah tersebut akan dimusyawarahkan kembali dengan karyawan. Pengawasan yang dilakukan PT. Pribumi Citra Megah Utama terhadap kegiatan keuangan adalah dengan melalui keputusan masalah investasi yang berada di keputusan pimpinan puncak, dan keputusan tersebut berkaitan dengan keputusan pada proses pemilihan alternatif investasi atas tujuan terhadap keuntungan yang diperoleh perusahaan.

\section{d. Sumber Daya Manusia}

Dalam pembuatan strategi sumber daya manusia pada PT. Pribumi Citra Megah Utama dengan melalui tahapan-tahapan sebagai berikut:

1) Mengetahui jenis karakter orang yang perlu dikelola dan yang hendak melakukan bisnis, dengan tujuan supaya sesuai dengan apa yang diharapkan oleh perusahaan atas tujuan bisnis strategi. 
2) Memikirkan jenis program dan inisiatif tentang sumber daya manusia yang harus didesain dan diterapkan untuk memikat, mengembangkan, dan mempertahankan staf agar berkompetisi secara efektif.

3) Perencanaan Sumber Daya Manusia

a) Penentuan kebutuhan tenaga kerja.

b) Uraian jabatan, uraian tugas, dan tanggung jawab terhadap masing-masing jabatan.

c) Spesifikasi jabatan, persyaratan yang harus dimiliki oleh satu jabatan tertentu.

\section{e. Rekruitmen dan Seleksi Sumber Daya Manusia}

Penjabaran dari proses rekruitmen tersebut diatas adalah:

1) Sumber-sumber rekruitmen, terdapat dua sumber yaitu:

a) Sumber dari dalam perusahaan, tiga bentuk mutasi pegawai yaitu promosi jabatan; transfer atau rotasi pekerjaan, dan demosi jabatan atau penurunan jabatan pegawai.

b) Sumber dari luar perusahaan, penarikan pegawai dengan melalui iklan media massa, lembaga pendidikan, depnaker, dan lamaran kerja yang masuk pada perusahaan pada waktu sebelumnya.

2) Seleksi calon pegawai, Proses seleksi melibatkan pilihan dari berbagai objek dengan mengutamakan beberapa objek saja yang dipilih, dan lebih ditekankan pada pengambilan keputusan dalam membatasi jumlah pegawai yang dapat dikontrakkerjakan dari pilihan sekelompok calon-calon pegawai yang berpotensi.

PT. Pribumi Citra Megah Utama dalam melakukan proses seleksi untuk memilih karyawan yang berkompeten, menurut salah seorang responden dalam penelitian ini selama ini perusahaan melakukan proses penyeleksiannya dengan melalui tes, wawancara dan praktek lapangan, sedangkan untuk proses rekruitmen dalam memilih karyawan yang berkompeten, dilakukan dengan berdasarkan pada pengetahuan serta pengetahuan yang dimiliki calon karyawan tersebut.

\section{f. Pelatihan dan Pengembangan Sumber Daya Manusia}

Pelatihan yang diberikan PT. Pribumi Citra Megah Utama agar dapat meningkatkan kualitas sumber daya manusia adalah dengan melakukan evaluasi terhadap karyawan setiap saat atau setiap minggu. Hal demikian bisa membuat PT. Pribumi Citra Megah Utama untuk bisa memberlakukan pelatihan. Pelatihan yang sering diberikan PT. Pribumi Citra Megah Utama kepada karyawan adalah yang berkaitan dengan tugas pada masing-masing divisi yang dimiliki perusahaan yaitu berupa mengikut sertakan karyawan yang berprestasi pada 
pelatihan atau kursus. PT. Pribumi Citra Megah Utama melakukan pengembangan sumber daya manusia dalam bentuk transformasi ilmu. Transformasi ilmu tersebut oleh perusahaan dilakukan kepada leader dengan teknisi atau karyawan yang berstatus sebagai karyawan senior kepada karyawan yang berstatus yunior, selain itu dengan transformasi ilmu dengan bahan berbagai buku panduan dalam kaitannya dengan keahlian masing-masing karyawan.

\section{g. Kompensasi}

Kompensasi diberikan PT. Pribumi Citra Megah Utama diberikan kepada karyawan sebagai bentuk balas jasa perusahaan atas kerja para karyawan. kompensasi diberikan sesuai dengan ketentuan yang diberlakukan oleh pemerintah, bahkan menurut salah satu informan dalam penelitian ini kompensasi diberikan kepada karyawan PT. Pribumi Citra Megah Utama melebihi ketentuan yang diberlakukan. Dalam hal kompensasi yang diberikan kepada karyawan, PT. Pribumi Citra Megah Utama memiliki regulasi sendiri yang disesuaikan dengan prestasi yang ditunjukkan oleh karyawan. Selain kompensasi tetap atau gaji tetap yang diberikan PT. Pribumi Citra Megah Utama kepada karyawan, perusahaan juga memberikan kompensasi dalam bentuk yang lain kepada karyawan berupa bonus apabila karyawan sukses menjalankan atau melaksanakan suatu pekerjaan yang menurut perusahaan penyelesaian atau pelaksanaan project tersebut melebihi ekspektasi yang ditentukan oleh perusahaan.

\section{h.Evaluasi Kinerja dan Produktivitas Karyawan}

PT. Pribumi Citra Megah Utama melakukan evaluasi terhadap kinerja semua karyawan yang dimiliki perusahaan tanpa terkecuali, evaluasi lebih difokuskan kepada karyawan yang bekerja dengan jangka waktu bekerja kurang dari satu tahun. Perusahaan juga menjadikan hasil dari kegiatan evaluasi terhadap kinerja karyawan sebagai sarana evaluasi untuk karyawan yaitu supaya karyawan termotivasi dan sebagai monitoring karyawan. Dalam hal promosi kepada karyawan perusahaan menentukan kriteria-kriteria tertentu terhadap masing-masing jabatan dengan jelas berdasarkan pada karyawan yang memiliki kompetensi dan berprestasi.

Produktivitas karyawan PT. Pribumi Citra Megah Utama dikaitkan dengan sikap mental produktif yang ditunjukkan karyawan menyangkut sikap motivatif, disiplin, kreatif, inovatif, dinamis, profesional dan berjiwa kejuangan dalam rangka memajukan perusahaan. Tingkat produktivitas yang dicapai karyawan PT. Pribumi Citra Megah Utama oleh perusahaan digunakan sebagai indikator pencapaian efisiensi dan kemajuan ekonomi 
perusahaan. Tingkat produktivitas karyawan PT. Pribumi Citra Megah Utama pada tingkat individu dinilai berdasarkan pada meningkatnya hasrat dan martabat karyawan atas adanya pengakuan terhadap berpotensinya individu di perusahaan, dan meningkatnya motivasi kerja serta adanya keinginan yang ditunjukkan karyawan untuk semakin meningkatkan prestasinya.

\section{Analisis Lingkungan Eksternal}

\section{a. Ancaman Pendatang Baru}

Menurut salah satu responden dalam penelitian ini pada kesempatan wawancara, potensi masuknya pendatang baru bagi perusahaan tidak masalah, karena pada tiap-tiap perusahaan sudah mempunyai pasarnya tersendiri. Bagi PT. Pribumi Citra Megah Utama, masuknya pendatang baru bagi perusahaan sejauh ini tidak memberikan dampak yang negative bagi perusahaan. Kondisi yang demikian tidak membuat PT. Pribumi Citra Megah Utama melakukan suatu tindakan antisipasi untuk menghambat masuknya pendatang baru tersebut. Aktivitas yang dilakukan PT. Pribumi Citra Megah Utama dilakukan sebagaimana rutinitas tiap harinya.

\section{b. Ancaman Produk Pengganti}

Pandangan yang ditunjukkan PT. Pribumi Citra Megah Utama perihal kekuatan produk pengganti dari produk-produk yang dihasilkan PT. Pribumi Citra Megah Utama tidak menimbulkan masalah yang terlalu signifikan, hal tersebut menurut salah satu responden bergantung pada kondisi di lapangan. Produk pengganti bagi PT. Pribumi Citra Megah Utama juga tidak memberikan dampak apapun. PT. Pribumi Citra Megah Utama dalam hal mengatasi hadirnya produk pengganti, perusahaan tidak melakukan hal apapun dan juga tidak melakukan tindakan antisipasi.

\section{B. Pembahasan}

\section{Analisis SWOT}

Analisis SWOT dalam penelitian ini digunakan untuk menganalisis kekuatan (strength), kelemahan (weaknes), peluang (opportunities) dan ancaman (threats) yang terdapat pada PT. Pribumi Citra Megah Utama.

1. Kekuatan (Strength)

a. Melakukan pengkoordinasian dengan membentuk suatu transformasi tugas dalam group yang aktif. 
b. Menciptakan kondisi kerja yang kondusif melalui transparatif dan terbuka antara karyawan dan pimpinan dalam bentuk musyawarah.

c. Perusahaan memberikan pelatihan profesional kepada karyawan untuk meningkatkan kualitas sumber daya manusia.

d. Perusahaan memberikan apresiasi kepada karyawan berupa peningkatan gaji dan jabatan.

e. Perusahaan sudah mengalokasikan potensi keuntungan jangka panjang atas kegiatan pemasaran.

2. Kelemahan (Weaknes)

a. Tindakan korektif atas terjadinya penyimpangan dilakukan hanya dengan peringatan lisan.

b. Masih ada kendala dalam hal proses pengawasan secara 24 jam, kekurangan supervise lapangan.

c. Perusahaan tidak melakukan analisa kebutuhan karyawan terhadap jenis pekerjaan tertentu.

d. Perusahaan tidak melakukan uraian pekerjaan untuk masing-masing jabatan.

e. Perusahaan masih memberlakukan sistem rolling apabila terdapat karyawan yang gagal menunjukkan kinerja terbaiknya.

f. Perusahaan dalam melakukan pengidentifikasian permintaan pasar masih sebatas mouth to mouth serta informasi dari koneksi.

g. Fungsi pemasaran masih belum berjalan dengan optimal.

3. Peluang (Opportunities)

a. Semakin banyak perusahaan yang menggunakan jasa bongkar muat kapal.

b. Belum banyak perusahaan sejenis yang menggunakan media internet untuk memasarkan jasa mereka.

4. Ancaman (Threats)

a. Perusahaan besar yang sejenis memiliki alat yang lebih bervariasi daripada milik PT. Pribumi Citra Megah Utama, seperti PT. Bunyamin Residence Banjarmasin dan Ciputra.

b. Semakin banyak individu yang ingin terjun dalam bisnis jasa bongkar muat kapal, sehingga terancam dapat mengurangi jumlah konsumen yang memakai jasa PT. Pribumi Citra Megah Utama. 


\section{Matriks SWOT}

Matriks SWOT oleh PT. Aneka Sejahtera Engineering digunakan sebagai tindakan dalam merumuskan strategi terhadap hasil dari analisis SWOT. Penetapan empat strategi yang terdapat dalam analisis SWOT dapat dilihat pada tabel berikut ini:

\section{Tabel Matrik SWOT PT. Pribumi Citra Megah Utama}

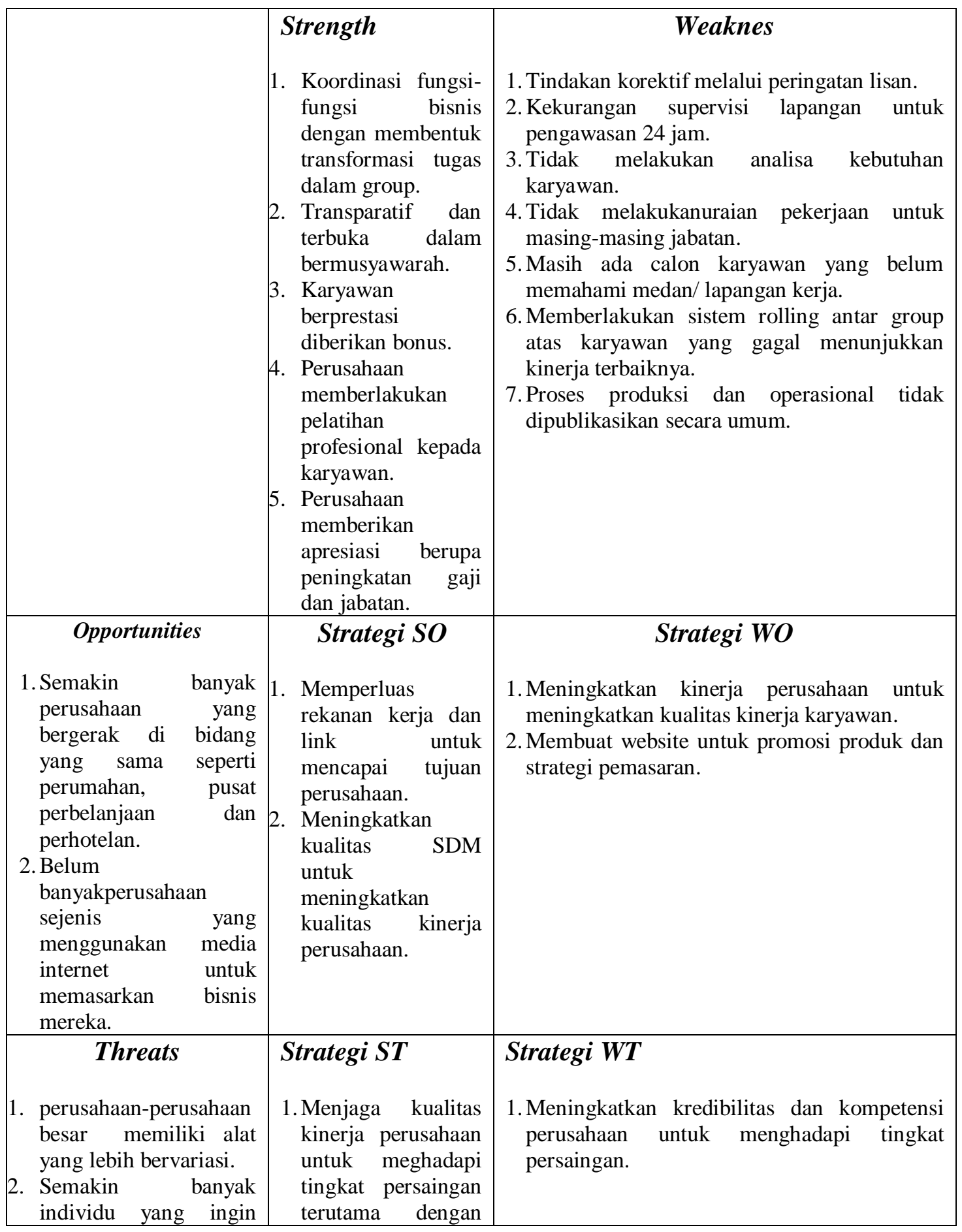




\begin{tabular}{|l|l|l|}
$\begin{array}{l}\text { terjun di bisnis jasa } \\
\text { bongkar muat kapal }\end{array}$ & $\begin{array}{l}\text { pesaing perusahaan } \\
\text { besar. }\end{array}$ & \\
\hline
\end{tabular}

\section{KESIMPULAN}

Berdasarkan Dalam pengelolaan bisnis yang terdapat pada PT. Pribumi Citra Megah Utama mencakup pada produksi dan operasional jasa layanan dan penjualan perumahan, pusat perbelanjaan serta perhotelan. Pemasaran, mengidentifikasi permintaan pasar dengan melalui mouth of mouth serta mendapat informasi dari koneksi perusahaan. Dalam hal untuk memenuhi permintaan pasar. Pengelolaan keuangan berkaitan dengan keputusan masalah investasi yang terdapat di perusahaan, yaitu merupakan keputusan masalah investasi terhadap fungsi-fungsi bisnis yang terdapat di perusahaan, dan untuk pengelolaan sumber daya manusia berkaitan dengan pembuatan strategi sumber daya manusia, perencanaan sumber daya manusia, rekruitmen dan seleksi sumber daya manusia, pelatihan dan pengembangan sumber daya manusia, kompensasi, evaluasi kinerja, dan produktivitas karyawan.

PT. Pribumi Citra Megah Utama hendaknya meningkatkan kinerja karyawan untuk meningkatkan kualitas kinerja perusahaan, dengan demikian perusahaan dapat menghadapi tingkat persaingan yang tinggi, dimana walaupun perusahaan tidak pernah merasa ada dampak dari adanya pendatang baru maupun persaingan antar perusahaan pesaing.

\section{DAFTAR USTAKA}

Allen, NJ., Meyer PJ. And Smith CA., 1993, "Commitment to Organizations and Occupations: Extention and Test of a Three-ComponentConceptualization", Journal of Applied Psychology, Vol. 78, No. 4

Amstrong, Michael, 1994, "Handbook of Personal Management Practise", 4th Edition, Kopan Page Ltd., London

Anwar Prabu Mangkunegara, DR., Msi., 2006, Evaluasi Kinerja SDM, Edisi Kedua, Refika Aditama, Bandung.

Bernadin, H. J. 2007. Manajemen Sumber Daya Manusia: Sebuah Pendekatan Eksponensial. Ed-4. NewYork: McGraw-Hill Irwin, 253-277.

Delaney, J. T. \& Huselid, M. A. 1996. " Dampak dari Praktek Manajemen Sumber Daya Manusia pada Persepsi dari Kinerja Organisasiee. Akademi Manajemen Journal, 39, 949- 69.

Dessler, G. 2003 Manajemen Sumber Daya Manusia. Jilid 2. Edisi Kesembilan. Jakarta: PT Indeks Kelompok Gramedia.

Francisca, Robert, 2017, Implementasi Total Quality Management Terhadap Budaya Kualitas, Al Ulum, Ilmu Sosial dan Humaniora, Vol. 3, No. 2, 2017. 
Gomez-Mejia, LR, Balkin, DB \& Cardy, RL 1998. Mengelola Sumber Daya Manusia. Prentice-Hall, Englewood Cliffs, NJ.

Hasibuan, M. S. P. 2006. Manajemen Sumberdaya Manusia. Edisi Revisi. Jakarta: Bumi Akasara.

Menard, S. 1995. Terapan Analisis Regresi Logistik. London: Sage.

Nitisemito, S. 1997. Pengembangan Sumber Daya Manusia. Jakarta: Balai Pustaka.

Patrick, J. 2000. "Pelatihan"e. Dalam N. Chmiel (Ed.) Pengantar Kerja dan Psikologi Organisasi (100-125). Oxford, Inggris: Blackwell.

Siagian, S. P. 2001. Manajemen Sumber Daya Manusia. Jakarta: Bumi Aksara.

Siagian, S. P. 2006. Manajemen Sumber Daya Manusia. Jakarta: PT. Bumi Aksara.

Vlachos, I. 2008. "Pengaruh Praktek Sumber Daya Manusia pada Kinerja Organisasi: Bukti dari Yunanie . International Journal of Manajemen Sumber Daya Manusia, 19 (1), 7497.

Wan, D., Kok, V. \& Ong, C. H. 2002. Strategis Manajemen Sumber Daya Manusia dan Kinerja Organisasi di Singapura. Kompensasi dan Manfaat Review, 34, 33-42.

Wright, P., Gardner, T., Moynihan, L. \& Allen, M. 2005. Hubungan antara Praktek SDM dan Kinerja Perusahaan: Memeriksa Urutan Kausal. 